\author{
Mile VAJKIĆ', Biljana VRANJE $\check{S}^{2}$ \\ Evica STOJILJKOVIĆ ${ }^{3}$, Marko ĐAPAN ${ }^{4}$
}

\title{
OCCUPATIONAL INJURY ANALYSIS IN THE FORESTRY OF THE REPUBLIC OF SRPSKA-BOSNIA AND HERZEGOVINA
}

\section{SUMMARY}

Forestry in the Republic of Srpska (BIH) is an important branch in industry, with the majority of activities in the field of forestry being conducted by the Public Forest Enterprise "Forests of the Republic of Srpska". From the aspect of occupational safety and health, forestry is a high-risk economic activity in which a large number of occupational injuries occur, often with fatalities. The basic task of occupational safety and health is to provide the best working conditions for all employees by designing occupational safety measures. To fulfil this task, the occupational injury analysis provides the opportunity to properly select preventive measures of protection and indicates the importance and magnitude of the problems related to occupational safety in the organization. Also, the analysis of certain etiological specificities of injury enables more accurate actions within the organization, with the aim of defining instructions for improving the risk management process in the organization. In this paper, occupational injury analysis in forestry was carried out in for the period 20112019 ., and obtained research results shows that $76 \%$ of injuries occur during woodcutting, and that about $60 \%$ of those injuries are related to the occupation of a cutter. Also, research see that the cause of injuries in $49 \%$ is the worker's negligence.

Keywords: forestry, occupational injury, risk management, occupational safety and health.

\section{INTRODUCTION}

Forestry, due to a large number of potential hazards and harms to the health and safety of workers, as well as the probability of accidents, is a challenge for occupational safety and health engineers to prevent occupational injuries and occupational deceases. Forest work is considered to be one of the most dangerous

\footnotetext{
${ }^{1}$ Mile Vajkić, (corresponding author: m.wajkic@gmail.com), High School of mechanical engineering, Prijedor, Republika Srpska, BOSNIA AND HERZEGOVINA.

${ }^{2}$ Biljana Vranješ, University of Banja Luka, Faculty of Mechanical engineering, Banja Luka, Republika Srpska, BOSNIA AND HERZEGOVINA.

${ }^{3}$ Evica Stoiljković, University of Niš, Faculty of Occupational Safety, Niš, SERBIA.

${ }^{4}$ Marko Đapan, University of Kragujevac, Faculty of Engineering, Kragujevac, SERBIA.

Notes: The authors declare that they have no conflicts of interest. Authorship Form signed online. 
occupations in the world (Lilley et al., 2002; Klun and Medved, 2007). Forest workers can still be found not wearing the compulsory safety equipment and ignoring safety rules and thus, accident rates are fairly high. Neither do most forest workers use personal protective equipment, although it is recommended in order to avoid serious and fatal accidents (Yoshimura and Acar, 2004). Application of safety equipment, such as safety trousers, decreases the number of accidents with chain saw, but on the other hand it in-creases the number of injuries of other unprotected body parts (Sullman et al. 1999). Europe-wide, the number of fatal occupational accidents in the agricultural, hunting and forestry sectors is higher than in any other (Kogler et al., 2015).An occupational injury is a change occurred in the work environment affecting one's integrity (physical, psychological and social), it occurred as a consequence of the sudden and immediate inconsistency between the behaviour of the person in the performance of work activity and the elements of the work environment (Krstić I., Anđelković B., 2013). Felling, cross-cutting, extraction and skidding operations are the most common operations that result in fatal forestry accidents. Each of the harvesting methods also has its specific features that depend on natural and production conditions, the technology used, and the share of manual operations in the overall process (Gerasimov and Sokolov, 2014). Exposure to the harms, which are largely present in the forestry, causes the onset of occupational diseases. Occupational diseases are those diseases which are caused by harms at the workplace that are caused by the longer direct influence of the work process and workplace conditions (Krstić I., Anđelković B., 2013). The large number of injuries which often have a fatal outcome, as well as the occurrence of occupational diseases due to exposure to numerous harms, classify forestry as a high-risk industry. In the world, the number of occupational injuries in forestry exceeds 170000 per year, while the number of fatal injuries ranges from 80 to 100 (Garland, J. J., 2018). Taking into account the facts, experiences and previous research in the field of occupational safety in forestry and collected data on accidents in The Public Forestry Enterprise "Forests of the Republic of Srpska", we decided to conduct this study to indicate the most important factors of accidents in forest operations. The aim of this analysis is to present the most common causes and sources of injuries at work in forestry in the Republic of Srpska (BIH) and to indicate the jobs where injuries most often occur. The results of this analysis contribute to a better organization of safety at work in forestry and enable more precise action in order to reduce risks in the workplace.

\section{MATERIAL AND METHODS}

Occupational injury analysis in forestry was carried out in The Public Forestry Enterprise "Forests of Republic of Srpska" for the period 2011-2019. The analysis was conducted on the basis of data obtained by the occupational safety service in The Public Forestry Company "Forests of Republika Srpska". Any injury (minor, severe, or fatal) in forest operations is recorded using special documents (report of injury). Report of injury contains information on the age 
and qualification of the person involved in the accident, time and place of the accident, activities and phase of work at the time of the accident, form and distribution of injuries, severity of the accident, source and cause of the injury.

In the period 2011-2019, this company managed $77 \%$ of forest resources in Republika Srpska (BIH) and employs an average of 4,500 workers. The main harvesting technology was motor-manual processing with a chainsaw. In addition to felling and pruning wood, actions were carried out in order to protect forests, maintain roads and watercourses and afforestation. Tractors, loading machinery and trucks were used for transport. An injury risk assessment was performed for all workplaces and all forest workers had standard protective equipment. In this paper for the period 2011-2019. the following analyzes were performed:

- injuries by type of employment,

- injuries by gender of the injured worker,

- injuries by educational degree of the injured,

- injuries by the place of occurrence of the injury,

- injuries by the season when they occurred,

- injuries by the day of the week in which the injury occurred,

- injuries according to the job classification,

- sources and causes of occupational injuries.

\section{RESULTS AND DISCUSSION}

Fatal accident statistics are generally the most accurate of all accident statistics in that they are not reported by the injured person and must be published in official records (Thelin, 2002; Lindroos and Burstrom, 2010). According to occupational accident reports gathered from a number of selected International Labour Office member states, the average estimated fatal occupational accident frequency rate in forestry, logging and related services was 14/100,000 workers. (Enez et al.,2014). The EU collects data on occupational injuries from the Member States. It is considered that the number of occupational injuries with fatal outcome is reliable, although there are also different ways of statistical observation.

In the legislation of the Republic of Srpska $(\mathrm{BIH})$, categorization of injuries by severity is: light, serious and fatal injuries. In the analyzed period (2011-2019), the RS forestry recorded 1265 minor injuries, 96 serious injuries and 8 fatal injuries. The smallest number of injuries was 133 in 2011, and the highest of 171 injuries at work was in 2017. For the period 2011-2019, the annual average number of injuries at work in RS is 1236 , therefore occupational injuries in forestry with an average annual number of 152 make up $12 \%$ of total injuries in the Republic of Srpska. Figure 1. shows the number of injuries, classified by severity, in the Republic of Srpska forestry.

From Figure 1 we can conclude that in the Republic of Srpska forestry, there is a trend of the increase in the total number of injuries at work, while in the case of fatal injuries there is a trend of slight downward, Figure 1. 


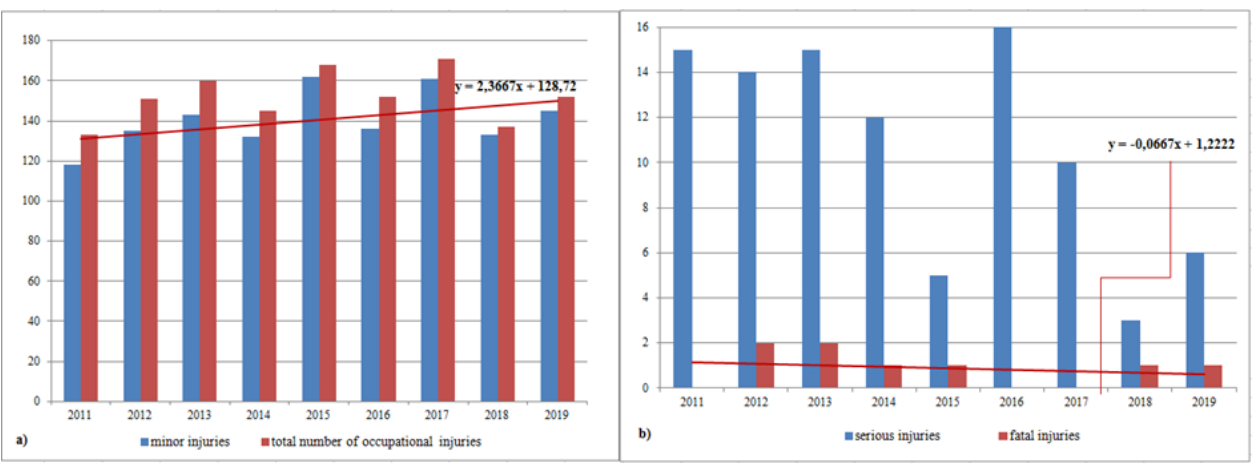

Figure 1. Overview of occupational injuries in the Republic of Srpska forestry for the period 2011-2019 (left-minor injuries and the total number of occupational injuries; Right -serious injuries and fatal injuries)

Occupational injury analysis involves analysis of the etiological components of injuries, such as gender, type of employment, educational degree, day of the week, place of occurrence, season, source and cause of the injury occurrence, etc. (Spasić, D., 2001.). An occupational injury analysis according to these etiological factors in the Republic of Srpska forestry is shown in Figure 2.

According to the data obtained on injuries in the RS forestry for the period 2011-2019, shown in the previous figure we conclude that: $97 \%$ of all injuries occur during regular working hours, that the male labour force is the most injured (96\%); that the most injured are workers with secondary education (47\%) and skilled workers $(38 \%)$; that the highest number of injuries occurs during cutting, felling, skidding and loading of wood (80\%); that injuries mostly happen during summer (33\%) and on Mondays (24\%). On the basis of the conducted research the result of occupational injuries by gender is expected because the male labour force is predominantly employed in this industry (Employees in the Public Forestry Company "Forests of Republika Srpska" by sex $90 \%$ men and $10 \%$ women). Also, the majority of employees in this industry are skilled workers and workers with secondary education, therefore the highest percentage of injured is among this population. In comparison to the seasons, injuries most often occur in the summer, due to the favourable weather conditions for outdoor work, although the prevalence of injuries in other seasons is large and quite equable.

According to the results of the conducted research, the operation of the occupational safety system and the design of safety measures should be directed to work operations performed during cutting, felling, skidding and loading of wood during regular working hours.

Also, the data shows that most injuries occur on Mondays, almost $1 / 4$ of all injuries, i.e. $24 \%$. This result can be explained by the inadequate use of free time during the weekend and the need to "break-in" in the work rhythm at the beginning of the workweek, which is strongly related to complex physical work, and this result is also present in the research of other authors (Šporčić, M., Sabo, A. 2002.; Musić, J. et al .2019.; Landekić, M. 2010). Organizational measures of 
worker preparation in the form of brief meetings to remind workers of the importance of following work procedures and procedures with an emphasis on the importance of following safety rules and the proper use of personal protective equipment and means, with a slower work pace, should be used as a measure to reduce the number of injuries at the beginning of the workweek.

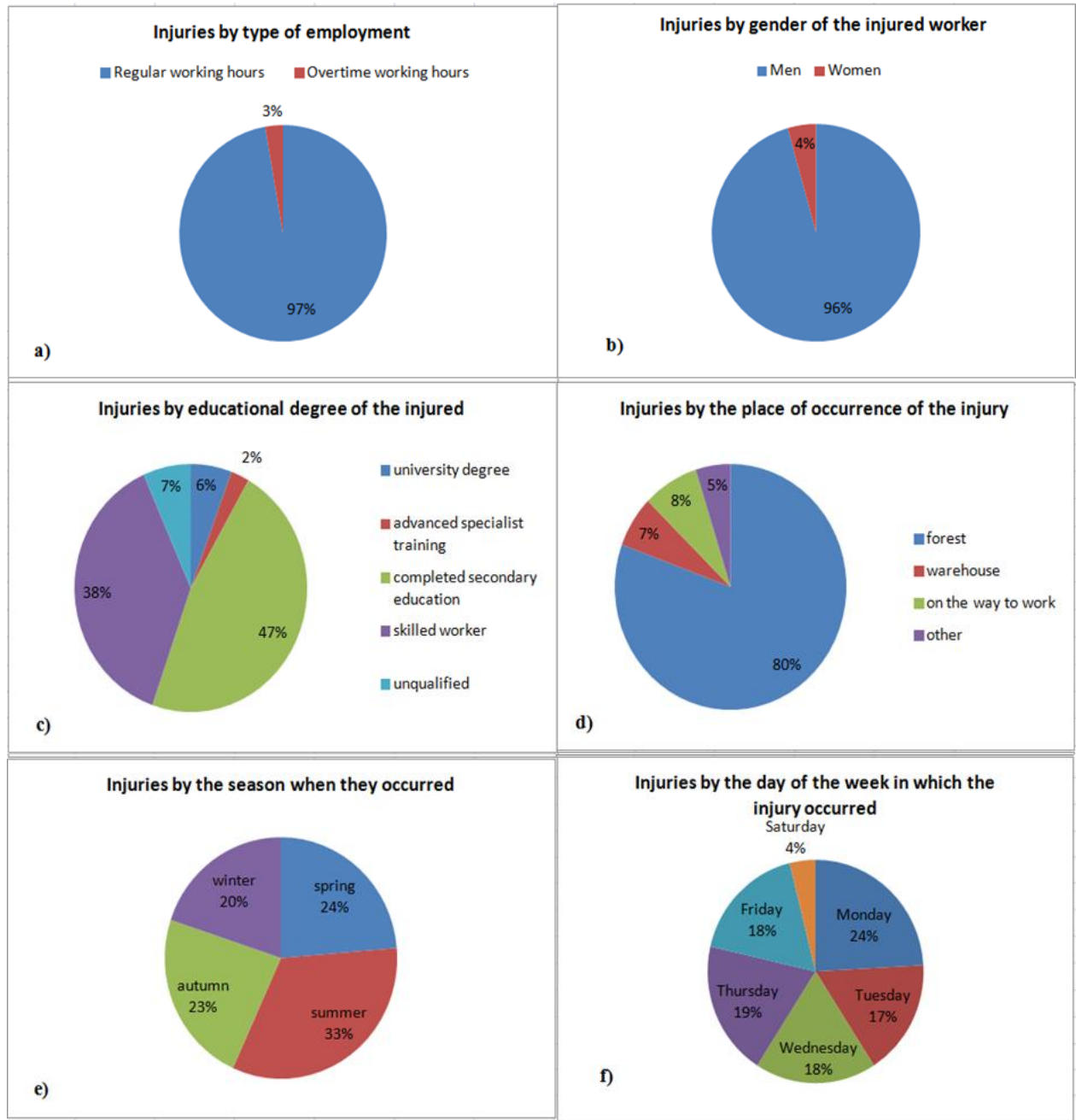

Figure 2. Etiological characteristics of occupational injuries in the Republic of Srpska forestry for the period 2011-2019

a) injuries by type of employment b) injuries by gender of the injured worker c) injuries by educational degree of the injured d) injuries by the place of occurrence of the injury e) injuries by the season when they occurred f) injuries by the day of the week in which the injury occurred

In the structure of injuries, according to the job classification (Figure 3), direct executors of woodworking operations (cutter, cutter assistant in forestry, 
tractor driver, chokersetter, receiver-shipper and auxiliary worker) participate with $76 \%$ of all injuries, with the riskiest job being the cutter with $38 \%$ of all the injuries that occurred in the analysed period.

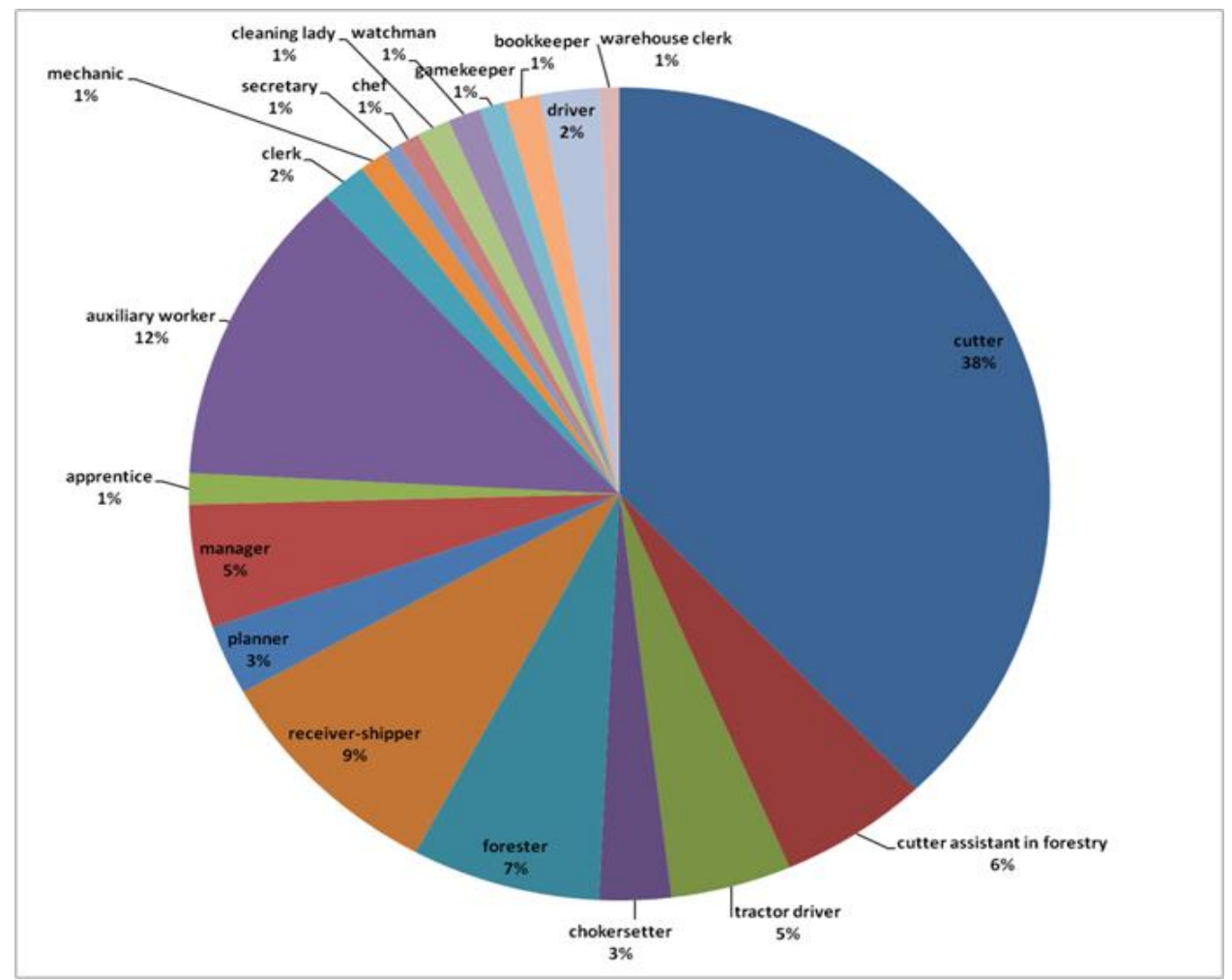

Figure 3. Structure of injuries according to the job classification in RS forestry

Of the etiological factors, from the aspect of designing occupational safety measures, the most important is to determine the source and cause of occupational injuries.

While the sources of injuries are related to material (means of labour, material, tools, etc.), energy and workplace factors that (by their direct effect on the organism of a worker) cause injuries; the causes of injuries are related to the reasons i.e. 'roots' of injuries, and they are difficult to be identified and divided into specific groups. This happens because the complex impact of multiple causes is often present. The most common causes of occupational injuries are (Vranješ, B., Tanasić, Z.,2017.):

- subjective causes dominated by the so-called human factor,

- objective causes related to the degree and duration of objective hazard/harm in the work environment and/or in the workplace or to the factors arising from the social environment.

The structure of occupational injuries in RS forestry by source and cause of injury is shown in Figure 4. 
Based on the results of the research, we can conclude that in $1 / 3$ of all injuries the source of the injury is the object of work-tree, and in more than $50 \%$ the sources are the object and means of work. Also, the source of injury in 19\% of cases is the substrate, so more attention should be paid to the selection and purchase of adequate work shoes adapted to field working conditions.

The largest number of fatal injuries occurs in tree felling. Tree felling should be carried out professionally following the safety measures for all workers in the forest. All workers who conduct tree felling should be at an adequate distance and out of the area of risk of a falling tree.

Injuries at work mostly occur when:

- the tree falls in the wrong direction;

- the constitution of the tree causes change in the direction of the fall;

- a falling tree knocks down other trees or knocks down branches from other trees;

- there are broken branches on the felling tree, which fall off during felling and pose a threat to the worker.

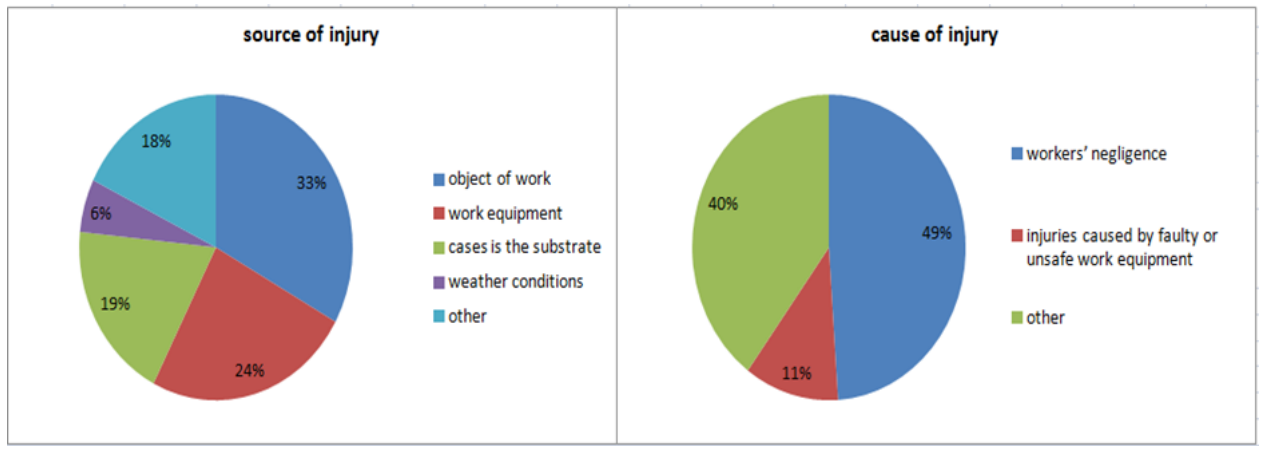

Figure 4. Sources and causes of occupational injuries in the Republic of Srpska forestry for the period 2011-2019.

While working in the forest, very dangerous operations are clearing broken trees, windthrow, damage caused by snow or sanation of the fire because of the unnatural position of trees etc. Applying technical measures for the protection of work means, safety procedures and rules for conducting work operations and training measures for workers are a good way of reducing the impact of these sources.

Theoretical sources and research data of other authors (Šporčić, M., Sabo, A. 2002). State that the most common cause of all occupational injuries is a person i.e. human error. Human error is a failure to perform a specific task, which may result in interruption of planned operations, damaging the equipment and property. 


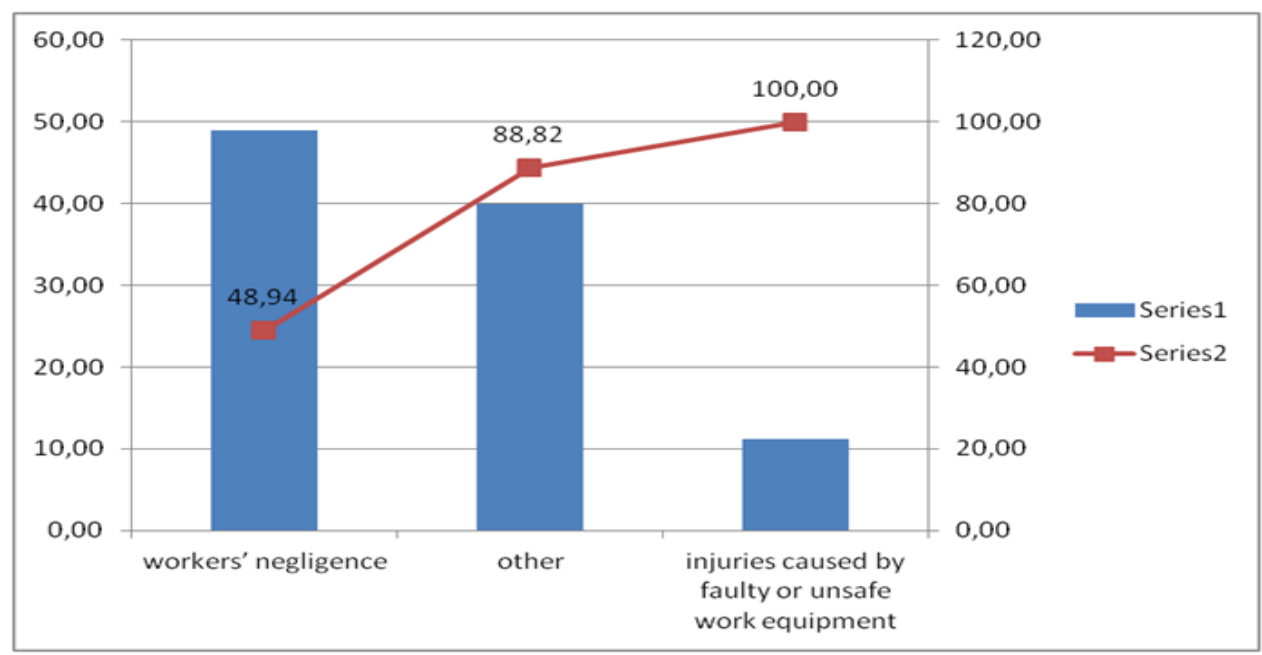

Figure 5. Pareto diagram

This error can occur due to numerous reasons: lack of precision, improper handling, lapses in recognition, cognitive and memory lapses, lapses in attention (fatigue, lack of alertness), etc. So, these are unwanted actions or activities that result in deviations from expected standard behaviours or norms, with people, equipment and system at risk (Stojiljković, E. 2020). The following figure shows the causes of occupational injuries in the Republic of Srpska forestry for the period 2011-2019 using the Pareto diagram. Based on the data obtained, we can conclude that negligence, not following safety rules, underestimation of danger, not using or misusing of personal protective equipment, etc. are the most common causes of injuries at work in forestry (e.g. in $49 \%$ of cases the cause of occupational injuries is workers' negligence). Also, according to the results obtained, we can clearly and accurately define measures of occupational safety and health at work, i.e. in what direction should we act in order to continuously reduce the risk in the workplace.

The cumulative curve of the Pareto diagram (Fig. 5) leads to the conclusion that in the system of occupational safety and health at work in forestry new forms of training and continuous education of employees for safe and healthy work and reduction of human errors should be defined, with emphasize on the significance and importance of following occupational safety measures. Considering that in $11 \%$ of all injuries that occurred the causes are the means of work, we can conclude that even technical measures for protection at work in forestry are not at an enviable level. Proper use of work means, regular inspection and maintenance of it, use of safety devices on work means, adequate use and maintenance of means and personal protective equipment etc. are some of the measures that can reduce the risk of injury at work in Republic of Srpska (BIH) forestry.

Conducting the research we found no data on occupational disease cases in this economic industry. 


\section{CONCLUSIONS}

Every occupational injury causes minor or major disruption to the work processes in every industry, including forestry. For this reason and due to the fact that only a healthy, satisfied and motivated employee can express his full work potential, special attention should be paid to occupational injury analysis in every working organization.

Etiological analysis of occupational injuries in RS-BIH forestry for the period 2011-2019 shows that 76\% of injuries occur during woodcutting, and that about $60 \%$ of those injuries are related to the occupation of a cutter. Also, we can see that the cause of injuries in $49 \%$ is the worker's negligence. In order to reduce the overall risk in the workplace of the company "Forests of the Republic of Srpska", it is necessary to act specifically in the area of cutting wood. It is imposed that the basic guideline for risk reduction is continuous education on safety and health at work, as well as an urgent modernization of the cutting process, that is, the automation of a cutter and auxiliary worker workplaces. By reducing the proportion of manual labour and increasing awareness about occupational safety and health, there would be a clear reduction in the number of occupational injuries. In forestry, an economic industry where workers are exposed to numerous dangers, lack of data about occupational diseases (from the aspect of occupational safety and health), is not acceptable.

Even if the occupational injury analysis shows that the by-laws do not directly affect the number and cause of injuries, it would be good to better define the measures of occupational safety and health in forestry. Also, outdated by-laws should be harmonized with other RS-BIH legislation and with modern guidelines on safety and health at work. More detailed regulation of safety and health at work of forestry workers would enable better and safer work in the field of forestry.

\section{REFERENCES}

Enez, K., Topbas, M., Acar, H.H., 2014. An evaluation of the occupational accidents among logging workers within the boundaries of Trabzon Forestry Directorate, Turkey. Int. J. Ind. Ergon. 44, 621-628.

Evropska komisija (2015). Zaštita zdravlja i sigurnosti radnika u poljoprivredi, stočarstvu,hortikulturi i šumarstvu. Luxembourg: Ured za publikacije Europske unije

Garland, J. J. (2018). Accident reporting and analysis in forestry: guidance on increasing the safety of forest work. In: Proceedings of the Forest Engineering Conference, vol. 17. Rotorua, New Zealand,.

Gerasimov, Y., Sokolov, A., 2014. Ergonomic evaluation and comparison of wood harvesting systems in Northwest Russia. Appl. Ergon. 45, 318-338.

ILO (1998). Safety and healthin forestry work. Geneva: International Labour Office.

Klun, J., Medved, M., 2007. Fatal accidents in forestry in some European countries. Croatian J. For. Eng. 28, 55-63. 
Kogler, R., Quendler, E., Boxberger, J., 2015. Analysis of occupational accidents with agricultural machinery in the period 2008-2010 in Austria. Saf. Sci. 72, 319-328.

Krstić I., Anđelković B. (2013). Profesionalni rizik. Niš: Univerzitet u Nišu, Fakultet zaštite na radu u Nišu.

Landekić, M. (2010). Organizacijska kultura i sigurnost pri radu u Hrvatskom šumarskom sektoru, Šumarski list br. 11-12, CXXXIV (2010), str. 613-622

Lilley, R., Feyer, A.M., Kirk, P., Gander, P., 2002. A survey of forest workers in New Zealand - Do hours of work, rest, and recovery play a role in accidents and injury? J. Saf. Res. 33, 53-71.

Lindroos, O., Burstrom, L., 2010. Accident rates and types among self-employed private forest owners. Accid. Anal. Prev. 42, 1729-1735.

Milijić, V. (2013). Zaštita na radu u šumi. Majdanpek: Resurs centar Majdanpek

Musić, J., Halilović, V., Lojo, A., Šporčić, M., Đonlagić, A. (2019). Analiza sigurnosti pri radu u šumarstvu Federacije BiH - studija slučaja. Nova mehanizacija šumarstva: časopis za teoriju i praksu šumarskoga inženjerstva, 40 (2019), Zagreb, https://doi.org/10.5552/nms.2019.4

Spasić, D .(2001). Ekonomika zaštite na radu. Niš: Grafičko preduzeće SVEN.

Stojiljković, E. (2020). Procena ljudske pouzdanosti. Monografija nacionalnog značaja. Niš: Univerzitet u Nišu, Fakultet zaštite na radu u Nišu.

Sullman M. J. M, P M. Kirk, R. Parker, J. E. Gaskin . 1999 , New Zealand Logging Industry Accident Reporting Scheme: Focus for a Human Factors Research Programme

Šporčić, M., Sabo, A. (2002). Ozlijeđivanje radnika u hrvatskom šumarstvu tijekom razdoblja 1991-2000, Šumarski list br. 5-6, CXXVI (2002), str. 261-271

Thelin, A., 2002. Fatal accidents in Swedish farming and forestry, 1988-1997. Saf. Sci. 40, 501-517.

Vranješ, B., Tanasić, Z. (2017). The application of the Ishikawa method for determining the cause of accidents at work, $13^{\text {th }}$ International Conference on Accomplishments in Mechanical and Industrial Engineering DEMI 2017, Banja Luka $26^{\text {th }}-27^{\text {th }}$ May 2017, pp. 827-834.

Yoshimura, T., Acar, H.H., 2004. Occupational safety and health conditions of forestry workers in Turkey. J. For. Res. 9, 225-232. 